\title{
Institutional Direction of Geospacial Information for Supporting Development Equality
}

\author{
Suprajaka', Aris Haryanto² \\ Badan Informasi Geospasial (BIG) \\ Anita Silalahi ${ }^{3}$, Nanda Noor ${ }^{4}$, Adi Pradana ${ }^{5}$ \\ World Resources Institute (WRI) Indonesia
}

\begin{abstract}
Spatial inequality occurs because the rate of availability of geospatial data has not been able to catch up and meet user needs. The root of the problem occurs because the network nodes in the area have not yet been formed or dissolved. The institutional status of network nodes at the provincial level as of October 2018, only 20 out of 34 provinces are operational, with 4 institutional options, namely UPT, Bappeda, Ad Hoc Regional Secretary and Ad Hoc Diskominfotik. This triggered anxiety for 14 regions that had not yet formed network nodes and 3 other UPTDs that were still awaiting evaluation results. To determine the institution of ideal geospatial information, BIG has conducted a study of institutional arrangements to realize effective and efficient regional apparatus organizations according to their duties and functions. The study with qualitative research methods was carried out by analyzing criteria and rating on institutional aspects in order to strengthen IDSN, based on applicable policies and laws as well as the results of the network node operationalization questionnaire in the province. Furthermore, the study was strengthened using quantitative research methods by comparing the costs and benefits of each institutional option (cost and benefit analysis) through the net present value approach. The results of the two methods are 2 alternative institutional geospatial information with the best value, namely Option 1 UPTB (Ideal for the long term) and Option 3 Ad Hoc in Regional Secretary (Quick Win for the medium term).
\end{abstract}

Keywords: institutional, spatial data infrastructure, economic costs and benefits analysis, One Data Policy, Indonesia 2045.

\footnotetext{
${ }^{1}$ Suprajaka is a Head of Center for Standardization and Institutional Geospatial Information at Badan Informasi Geospasial, Indonesia.

${ }^{2}$ Aris Haryanto is a Head of Institutional Development and Geospatial Information Network Node at Badan Informasi Geospasial, Indonesia.

${ }^{3}$ Anita Silalahi is a Legal Analyst One Map Initiative at World Resources Institute, Indonesia

${ }^{4}$ Nanda Noor is a Sustainable Land Use Project Lead at World Resources Institute, Indonesia. Email: nanda.noor@wri.org

${ }^{5}$ Adi Pradana is a Sustainable Land Use Manager at World Resources Institute, Indonesia.
} 


\section{Arah Kelembagaan Informasi Geospasial yang Mendukung Pemerataan Pembangunan}

\section{Suprajaka, Aris Haryanto, Anita Silalahi, Nanda Noor, dan Adi Pradana}

\section{Pendahuluan}

\subsection{Latar Belakang}

Menyongsong Indonesia Emas tahun 2045, Presiden Joko Widodo optimis bahwa perekonomian Indonesia berpotensi menempati posisi ke-4 terkuat di dunia setelah China, India, dan Amerika Serikat (PwC, 2015:5). ${ }^{6}$ Untuk mencapai target tersebut, menurut kalkulasi Menteri Perencanaan Pembangunan Nasional, skenario pertumbuhan ekonomi diharapkan meningkat rata-rata 5\%, agar mendorong pemerataan pembangunan antar wilayah melalui kebijakan afirmatif pada daerah - daerah yang tertinggal (Brodjonegoro, 2017:31). Dengan paradigma Holistik, Integratif, Tematik dan Spasial (HITS), maka informasi geospasial yang akurat menjadi kunci sukses bagi pencapaian sasaran dan target pembangunan ini secara akurat dan efisien.

Strategi pemerataan pembangunan 2045 menurut Bappenas akan dilakukan dengan: a) Perkuatan basis-basis perekonomian kawasan timur Indonesia; b) Pengembangan kota-kota baru dan pusat-pusat produksi dan perdagangan; c) Perkuatan rantai industri hulu hilir produk unggulan berbasis sumberdaya lokal; d) Penyediaan prasarana dan sarana transportasi, informasi dan komunikasi (Bambang Brodjonegoro, 2017:54). Peluang terwujudnya strategi pemerataan pembangunan tersebut perlu ditunjang dengan keberadaan kelembagaan informasi geospasial yang andal. Simpul jaringan akan menjadi garda terdepan penyedia basis dan analisis data spasial yang akurat, presisi dan berkualitas dalam rangka pengambilan berbagai kebijakan pembangunan, sekaligus pelaksana dari Kebijakan Satu Data dan Satu Peta (KSP) yang terintegrasi.

Prestasi Indonesia saat ini menurut data yang dirilis World Economic Forum menunjukkan indeks daya saing global (Global Competitiveness Index) 2018 maju ke peringkat 45 dari 140 negara. Selain itu, Index Kemudahan Berusaha Indonesia (Ease of Doing Business) 2018 yang dirilis oleh World Bank juga membaik di posisi 72 dari 190 negara. Data ini memberi kesan positif bagi para investor untuk meningkatkan investasi mereka di Indonesia.

\footnotetext{
${ }^{6}$ Pidato Presiden pada Rakernas II DPRD Kabupaten Seluruh Indonesia di Jakarta pada 27 Maret 2018. Prediksi ini berdasarkan hasil kajian Price Waterhouse Coopers (PWC), "The World in 2050, Will the Shift of The Global Economic Power Continue?", February 2015, hal. 5.
} 
Meskipun demikian, masih banyak disparitas atau ketimpangan spasial antar daerah yang membuat pencapaian sasaran pemerataan pembangunan belum optimal. Indonesia sangat membutuhkan basis dan analisis spasial yang kuat, dalam rangka pemanfaatan potensi sumber dayanya, yakni sebagai negara kepulauan dan maritim terbesar di dunia dengan luasan wilayah 1,904,569 km² dan garis pantainya $25 \%$ dari panjang pantai dunia (www.visitindonesia2010.wordpress.com, 2013). Namun ketimpangan spasial terjadi karena laju ketersediaan data geospasial belum dapat mengejar dan memenuhi kebutuhan pengguna. Akar permasalahan terjadi karena simpul jaringan di daerah belum terbentuk atau dibubarkan.

Ketimpangan spasial ini menghambat pemerataan pembangunan karena terbatasnya basis dan analisis data spasial mengenai potensi sumber daya yang memadai antara perdesaan dan perkotaan, antara Pulau Jawa dan luar Jawa, antara pusat-pusat pertumbuhan dan kawasan perbatasan, serta antara Kawasan Barat dan Kawasan Timur Indonesia. Ketersediaan peta skala sedang-besar masih belum komplit, teratur, dan mutakhir sehingga belum mampu mendukung penuh kebutuhan pemerataan pembangunan nasional.

Gambaran kondisi ini tampak dari data Direktorat Toponimi dan Batas Wilayah Kementerian Dalam Negeri bahwa pemetaan terkait penyelesaian batas daerah pada skala 1:50.000 (status per Juli 2018) antar provinsi baru mencapai 61,2\% dari 165 segmen dan antar kabupaten/kota baru 49,8\% dari 812 segmen (Simanjuntak, 2018:5). Kemudian status pemetaan batas wilayah administrasi desa/kelurahan tahun 2017 baru mencapai 12.159 dari total 82.384 (Abidin, 2018:29). Selain itu, data BIG untuk ketersediaan peta Rupa Bumi Indonesia dan Lingkungan Pantai Indonesia skala besar (1:5.000 - 1:1.000) pada RKP 2016 baru tersedia kurang dari 2\% (Abidin, 2018:20). Sedangkan kebutuhannya semakin tinggi pada RKP 2019 terkait dengan pengembangan pemetaan tematik untuk pemerataan pembangunan, antara lain pemetaan batas desa, pembangunan KEK dan KI, pembangunan smart city, percepatan sertifikasi tanah, serta mitigasi dan adaptasi bencana.

Tidak dapat dipungkiri bahwa ketersediaan data spasial yang cepat, akurat, dan dapat dipertanggungjawabkan bergantung pada profesionalitas kelembagaan penyelenggaranya. Mempertimbangkan kondisi Badan Informasi Geospasial (BIG) yang tidak memiliki instansi cabang di daerah, maka ketersediaan data spasial untuk kebutuhan pembangunan tergantung pada operasionalisasi simpul jaringan.

Untuk itu, BIG telah berperan aktif dalam membina simpul jaringan. Namun demikian, kelembagaan JIGN saat ini baru pada tahap pengembangan, belum dapat sepenuhnya lepas landas untuk mewujudkan keberhasilan Visi Indonesia 2045 dalam rangka mendukung pemerataan pembangunan. Status kelembagaan informasi geospasial di Indonesia di tingkat pusat hingga Oktober 2018, baru 9 dari 19 Kementerian/Lembaga yang simpul jaringannya telah operasional. Sementara di tingkat daerah, baru 20 dari 34 provinsi yang 
operasional, dengan 4 bentuk opsi kelembagaan. Posisi 14 provinsi lainnya masih business-as-usual atau sedang tahap legalisasi pembentukan kelembagaan, seperti tertera pada Tabel 1 berikut (BIG, 2018):

Tabel 1. Bentuk Kelembagaan Simpul Jaringan di Tingkat Provinsi

\begin{tabular}{|c|c|c|c|c|c|}
\hline No. & Business as usual/ drafting & $\begin{array}{l}\text { Opsi } 1 . \\
\text { UPTD }\end{array}$ & $\begin{array}{l}\text { Opsi } 2 . \\
\text { Bappeda }\end{array}$ & $\begin{array}{c}\text { Opsi 3. Ad } \\
\text { Hoc di } \\
\text { Sekda }\end{array}$ & $\begin{array}{c}\text { Opsi } 4 . \\
\text { Diskominfo }\end{array}$ \\
\hline $\begin{array}{l}1 . \\
2 . \\
3 . \\
4 . \\
5 . \\
6 . \\
7 . \\
8 . \\
9 . \\
10 . \\
11 . \\
12 . \\
13 . \\
14 .\end{array}$ & $\begin{array}{l}\text { Kepulauan Riau } \\
\text { Jambi } \\
\text { Bengkulu } \\
\text { Sumatera Barat } \\
\text { Banten } \\
\text { Bali } \\
\text { Nusa Tenggara Barat } \\
\text { Nusa Tenggara Timur } \\
\text { Kalimantan Tengah } \\
\text { Sulawesi Utara } \\
\text { Sulawesi Tenggara } \\
\text { Sulawesi Barat } \\
\text { Gorontalo } \\
\text { Papua Barat }\end{array}$ & $\begin{array}{l}\text { Nangroe } \\
\text { Aceh D. } \\
\text { Lampung } \\
\text { DI. } \\
\text { Yogyakarta } \\
\text { Jawa Timur } \\
\text { Jawa Barat } \\
\text { Kalimantan } \\
\text { Timur } \\
\text { Papua }\end{array}$ & $\begin{array}{l}\text { Sumatera } \\
\text { Selatan } \\
\text { Bangka } \\
\text { Belitung } \\
\text { Kalimantan } \\
\text { Barat } \\
\text { Kalimantan } \\
\text { Utara } \\
\text { Sulawesi } \\
\text { Tengah } \\
\text { Sulawesi } \\
\text { Selatan } \\
\text { Maluku } \\
\text { Mauku } \\
\text { Utara }\end{array}$ & $\begin{array}{l}\text { Sumatera } \\
\text { Utara } \\
\text { DKI Jakarta } \\
\text { Kalimantan } \\
\text { Selatan }\end{array}$ & $\begin{array}{l}\text { Riau } \\
\text { Jawa } \\
\text { Tengah }\end{array}$ \\
\hline
\end{tabular}

Tantangan utama yang dihadapi simpul jaringan daerah sejak 2017 adalah pembubaran 3 (tiga) Unit Pelaksana Teknis Daerah (UPTD). Hasil evaluasi perangkat daerah oleh Kementerian Dalam Negeri c.q. Direktorat Jenderal Otonomi Daerah c.q. Direktorat Fasilitasi Kelembagaan dan Kepegawaian Perangkat Daerah melingkupi UPTD bidang penyelenggaraan data spasial di bawah Bappeda, sesuai Peraturan Menteri Dalam Negeri (Permendagri) No. 12 Tahun 2017 Tentang Pedoman Pembentukan dan Klasifikasi Cabang Dinas dan UPTD. Dari hasil evaluasi tersebut, 3 (tiga) UPTD telah dibubarkan hingga Agustus 2018, yaitu UPTD Pusat Data dan Analisis Pembangunan Provinsi Jawa Barat, UPTD Pemetaan (One Map One Data) Kalimantan Timur dan UPTD Penataan Ruang dan Geospasial Provinsi Jawa Timur.

Selama ini, ketiga UPTD tersebut telah menjadi rujukan pembentukan simpul jaringan bagi daerah lainnya, karena berprestasi sebagai penerima anugerah "Bhumandala Award" untuk simpul jaringan terbaik. Oleh karena itu, Gubernur Aceh dan Gubernur Kalimantan Timur tetap berupaya keras mempertahankan bentuk kelembagaan UPTD karena prestasi dan historisnya. Sementara 3 UPTD lain yaitu di Provinsi Aceh, Lampung, dan Papua sampai kini masih cemas menunggu keputusan hasil evaluasi.

Pembubaran UPTD ini telah membuat 14 pemerintah provinsi lain yang belum membentuk simpul jaringan bertambah galau karena ketidakjelasan kebijakan yang ada. Padahal menurut Surat Edaran Menteri Dalam Negeri No. 503/685A/SJ tanggal 2 Februari 2018 tentang Penyiapan Infrastruktur dan Jaringan untuk Kebijakan Satu Peta bagi Pemerintah Daerah, diatur bahwa 
Gubernur wajib untuk menunjuk Unit Teknis OPD sebagai simpul jaringan dalam rangka pembangunan Jaringan Informasi Geospasial Nasional, yang bertanggung jawab dalam pencapaian target rencana aksi KSP.

Arahan Kementerian Dalam Negeri sebelumnya mempertegas pembentukan UPTD. Untuk memperkuat struktur kelembagaan pembangunan daerah yang membidangi data dan informasi pembangunan di Bappeda, maka dapat dibentuk UPTD sesuai peraturan perundang-undangan (poin 3 Surat Edaran Plt. Dirjen. Bina Pembangunan Daerah Kementerian Dalam Negeri No. 050/3770/Bangda tanggal 5 Agustus 2016 Tentang Pengendalian dan Evaluasi Perencanaan Pembangunan Daerah dan Data Pembangunan Daerah). Keterangan ini didetailkan pada Gambar 1 berikut.

Gambar 1. Dampak Pembubaran UPT dan Ketiadaan Simpul Jaringan

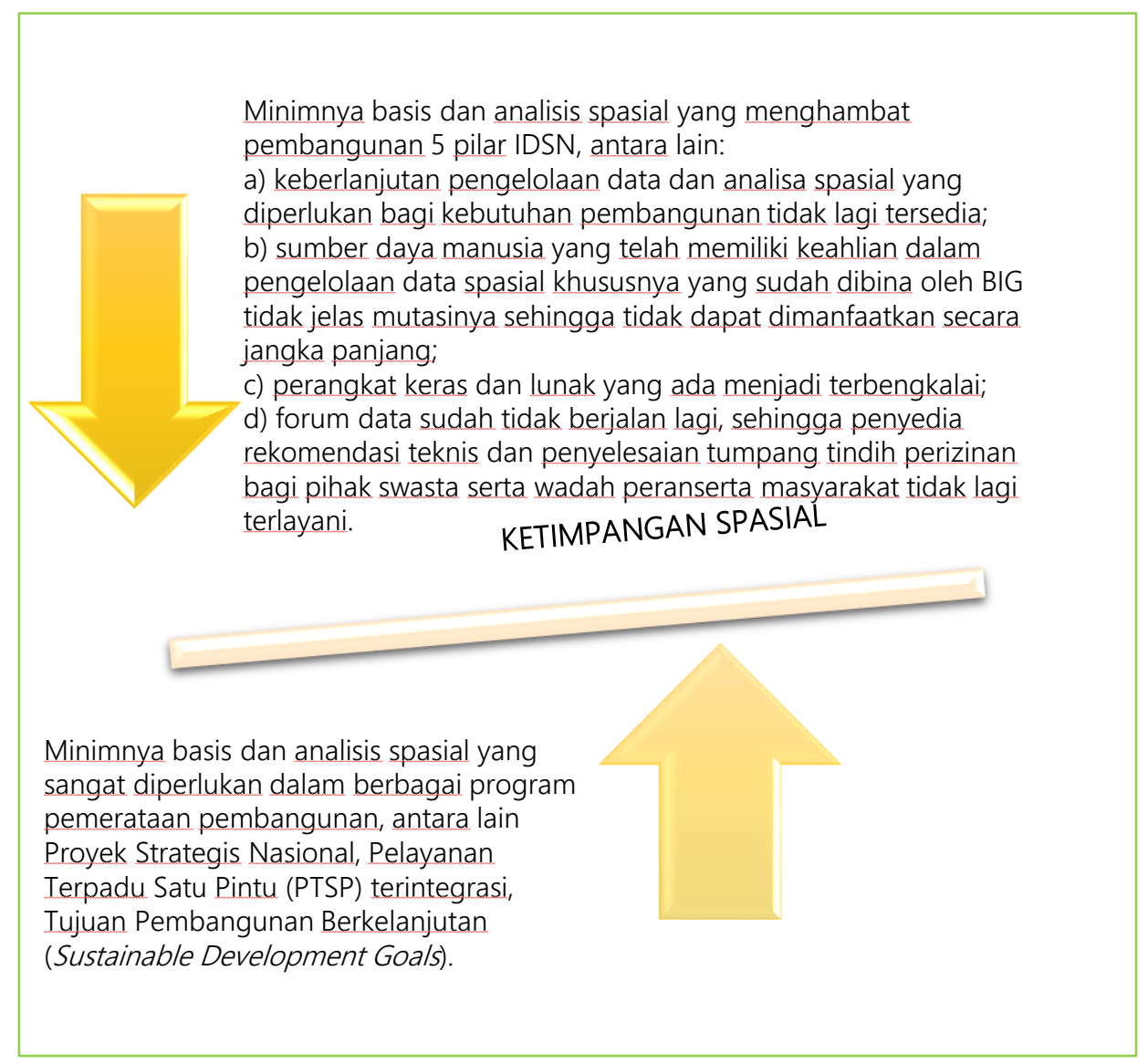

Tantangan lain dalam pelaksanaan KSP belum memberikan dukungan yang memadai untuk pengembangan Infrastruktur Data Spasial Nasional (IDSN) melalui simpul jaringan. Tahapan percepatan KSP memiliki tumpuan utama pada penyelenggaraan data, yakni mulai dari tahap kompilasi, integrasi, 
sinkronisasi dan penyelesaian konflik, yang dilaksanakan secara terpusat melalui 2 satuan tugas di dalam Sekretariat Percepatan Kebijakan Satu Peta pada Kementerian Koordinator Bidang Perekonomian. Padahal ketersediaan data spasial itu bukan hal yang instan, melainkan buah dari integrasi 5 pilar Infrastruktur Data Spasial Nasional (IDSN) sebagai kesatuan sistem, yakni kebijakan, kelembagaan, teknologi, standar dan data, serta sumberdaya manusia, dengan kategori detailnya pada Lampiran Tabel 1.

Hambatan esensial yang kerap terjadi sebagai akibat diabaikannya pengembangan IDSN melalui simpul jaringan adalah: a) peta dengan tema yang sama diterbitkan lebih dari satu lembaga tanpa koordinasi; b) beberapa peta tidak diterbitkan oleh instansi yang berwenang; c) hasil analisis IG yang berbeda (contoh jumlah pulau dan luas wilayah hutan); d) tumpang tindih lahan yang menggunakan izin (lisensi); e) IGD masih jarang digunakan sebagai dasar untuk membuat peta tematik; f) citra satelit untuk wilayah yang sama dibeli oleh lebih dari satu lembaga, padahal biayanya begitu tinggi (Abidin, 2018:41). Dari sisi ekonomi, hal ini dapat menimbulkan pemborosan anggaran pemerintah dan inefisiensi. Oleh karena itu, komitmen penataan kelembagaan simpul jaringan menjadi salah satu faktor penting dalam penyelenggaraan data yang akurat, berkualitas dan efisien untuk mendukung pemerataan pembangunan. Faktor utama Simpul Jaringan dalam pengembangan IDSN terdapat pada Lampiran Tabel 2.

Menuju era integrasi Satu Data dan keterbukaan pemerintah (Open Government), salah satu prinsip umum yang dikembangkan pemerintah untuk menyelenggarakan satu data yang akuntabel dan berintegritas adalah didasarkan pada sistem informasi geospasial Indonesia. Hal ini menunjukkan benang merah yang kuat bahwa Kebijakan Satu Data akan menjadi payung besar bagi Kebijakan Satu Peta, karena lingkup data mencakup juga data geospasial dan kelembagaan JIGN akan terintegrasi ke dalam kelembagaan Satu Data (Pusdatin Bappenas, 2018:24). Oleh karena itu, tata kelola data yang baik tidak terlepas dari pembenahan kelembagaan sebagai pelaksana dan penanggung jawab berbagi pakai data untuk kebutuhan pembangunan.

Dengan demikian, berbagai fakta tentang simpul jaringan informasi geospasial amat relevan untuk dikaji agar terintegrasi dalam penyelenggaraan satu standar data, satu metadata baku dan satu portal data dapat tercapai secara tepat sasaran. Keempat opsi simpul jaringan tersebut berpotensi sebagai embrio kelembagaan dalam Kebijakan Satu Data Indonesia (KSDI). Pada Rancangan Peraturan Presiden tentang Satu Data Indonesia, kelembagaan Dinas Telekomunikasi dan Informatika sebagai wali data dan Bappeda sebagai Sekretariat Satu Data sudah diatur. Sementara alternatif kemungkinan kelembagaan lain, seperti Unit Pelaksana Teknis Dinas pada Bappeda maupun Ad Hoc di Sekretaris Daerah masih luput dalam radar pembahasan.

Dalam rangka penataan kelembagaan, maka Badan Informasi Geospasial (BIG) bersama World Resources Institute (WRI) Indonesia melakukan 
kajian di 34 provinsi pada Mei - Juli 2018. Kajian ini dilakukan dengan menggunakan analisa kelembagaan dan biaya manfaat (Cost and Benefit Analysis/CBA) (Silalahi dan Siyaranamual, 2018). Kajian dengan analisa kelembagaan menilai pencapaian simpul jaringan terhadap penguatan Infrastruktur Data Spasial Nasional (IDSN). Selanjutnya kajian ini didukung dengan penilaian biaya dan manfaat untuk menentukan kelembagaan terbaik karena memiliki Net Present Value (NPV) kumulatif tertinggi (Siyaranamual, 2018:13).

\subsection{Permasalahan}

Dari latar belakang ini, pertanyaan penelitian yang ditarik adalah:

a) Kelembagaan simpul jaringan informasi geospasial apa yang dibutuhkan demi keberhasilan pemerataan pembangunan sesuai Visi Indonesia 2045?

b) Bagaimana strategi dan tahapan kelembagaan ini dalam mencapai sasaran pemerataan pembangunan sesuai Visi Indonesia 2045?

\subsection{Tujuan, Manfaat dan Keluaran}

Kajian ini bertujuan untuk mendapatkan kelembagaan simpul jaringan daerah terbaik, dengan menilai kualitas 4 opsi kelembagaan di daerah berdasarkan indikator penguatan 5 pilar IDSN. Kemudian hasilnya akan didukung dengan penilaian kuantitas melalui perbandingan biaya-manfaat dari keempat opsi kelembagaan di daerah sebagai penyedia basis dan analisis spasial yang berkelanjutan, dalam rangka mendukung pemerataan pembangunan, yang sejalan dengan KSP dan KSDI.

Ada 4 (empat) jenis kelembagaan yang akan dibandingkan, yaitu: Opsi (1) UPTD, Opsi (2) Bappeda, Opsi (3) Ad Hoc di Sekretaris Daerah (Sekda), dan Opsi (4) Dinas Telekomunikasi, Informatika dan Statistik (Kominfotik).

Kajian ini strategis untuk mendukung pemerataan pembangunan sesuai Visi Indonesia 2045, karena lembaga yang kuat menjadi kunci sukses penyediaan basis dan analisis spasial, yang dibutuhkan dalam perencanaan, pelaksanaan dan pengendalian program pembangunan dari aspek keruangan. Keberlanjutan peran JIGN dalam berbagi pakai data akan terintegrasi dengan kelembagaan KSP dan Kebijakan Satu Data Indonesia (KSDI).

Kajian ini bermanfaat untuk menentukan bentuk kelembagaan simpul jaringan informasi geospasial daerah terbaik dalam rangka mendukung pemerataan pembangunan sesuai Visi Indonesia 2045, yang sejalan dengan KSP dan KSDI. Alternatif opsi kelembagaan informasi geospasial daerah terbaik serta strategi dan tahapan yang jelas dalam pencapaian sasaran dan visi Indonesia 2045.

\subsection{Kerangka Berpikir}

Penataan kelembagaan simpul jaringan informasi geospasial daerah diarahkan untuk mewujudkan organisasi perangkat daerah yang efektif dan 
efisien sesuai tugas dan fungsinya. Untuk itu. penelitian kualitatif dilakukan dengan analisa terhadap aspek kelembagaan dalam rangka penguatan IDSN, berdasarkan kebijakan dan hukum yang berlaku serta hasil angket operasionalisasi simpul jaringan di provinsi (BIG, 2018).

Penilaian kualitatif ini selanjutnya didukung dengan penilaian kuantitatif dengan cara membandingkan antara biaya dan manfaat secara moneter dari masing-masing opsi kelembagaan, dengan memperhitungkan biaya dan manfaat yang terjadi saat ini dan yang akan terjadi di masa depan. Kemudian biaya dan manfaat yang terjadi di masa depan akan disetarakan ke dalam nilai moneter untuk waktu yang sama dengan menggunakan teknik diskonto, yaitu didiskontokan kembali ke tahun referensi (umumnya tanggal dimulainya evaluasi) untuk menghitung nilai sekarang dari arus kas bersih (Siyaranamual, 2018).

Secara umum, layanan simpul jaringan informasi geospasial yang baik berpotensi untuk meningkatkan manfaat produktivitas kinerja pemerintah dalam mencapai tujuan pembangunan nasional. Hubungan antara penyedia dengan pengguna informasi geospasial serta kaitannya dengan pertumbuhan inklusif tertera pada Gambar 2 berikut.

Gambar 2. Identifikasi Manfaat dan Biaya terkait Informasi Geospasial

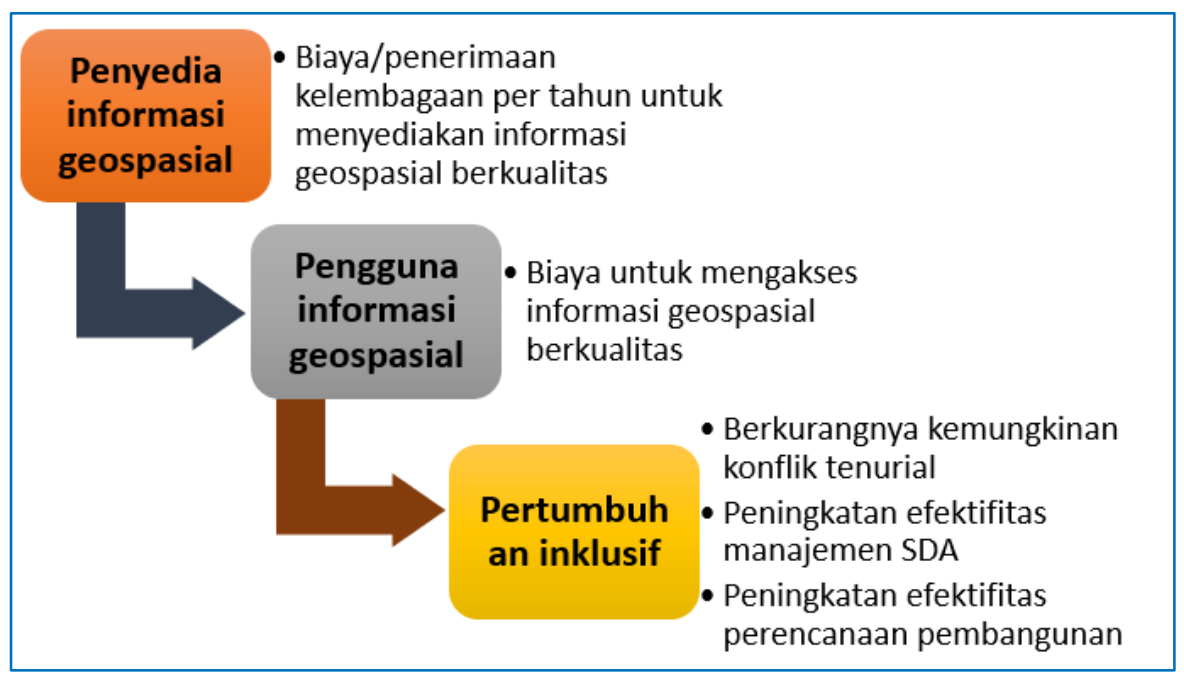

Secara khusus, nilai tambah dari keberadaan simpul jaringan informasi geospasial, antara lain (Siyaranamual, 2018):

a. efisiensi dalam berbagai kegiatan yang berujung pada penghematan biaya;

b. penurunan biaya bagi pemerintah dalam mengelola layanan publik yang berkaitan dengan masalah lingkungan hidup, kesehatan, dan sosial;

c. meningkatnya hasil penelitian yang berujung pada penciptaan inovasi dan nilai tambah baru yang sebelumnya tidak dimungkinkan; dan 
d. peningkatan kualitas informasi pengelolaan kekayaan negara khususnya yang berasal dari alam.

Dalam perspektif ekonomi, salah satu dasar penentuan bentuk lembaga yang paling efektif dalam membantu peran BIG di daerah adalah lembaga dengan net present value (NPV) kumulatif tertinggi. Analisis ini mempertimbangkan bahwa biaya dan manfaat tidak hanya diperoleh pada tahun awal periode perhitungan, namun juga di masa mendatang, sehingga seluruh nilai harus diubah ke dalam present value yang kemudian dibandingkan untuk mengeluarkan angka selisih berupa NPV. Perhitungan CBA ini mengasumsikan tiap provinsi memiliki kualitas IG yang sama dan manfaat muncul setelah tahap persiapan usai (tahun 2022), dengan tingkat diskonto 5\% per tahun selama 15 tahun terhitung sejak 2018. Kerangka bekerja spesifik pada NPV ini dijelaskan pada Gambar 3 berikut ini.

Gambar 3. Metode Net Present Value dalam Perhitungan Ekonomi

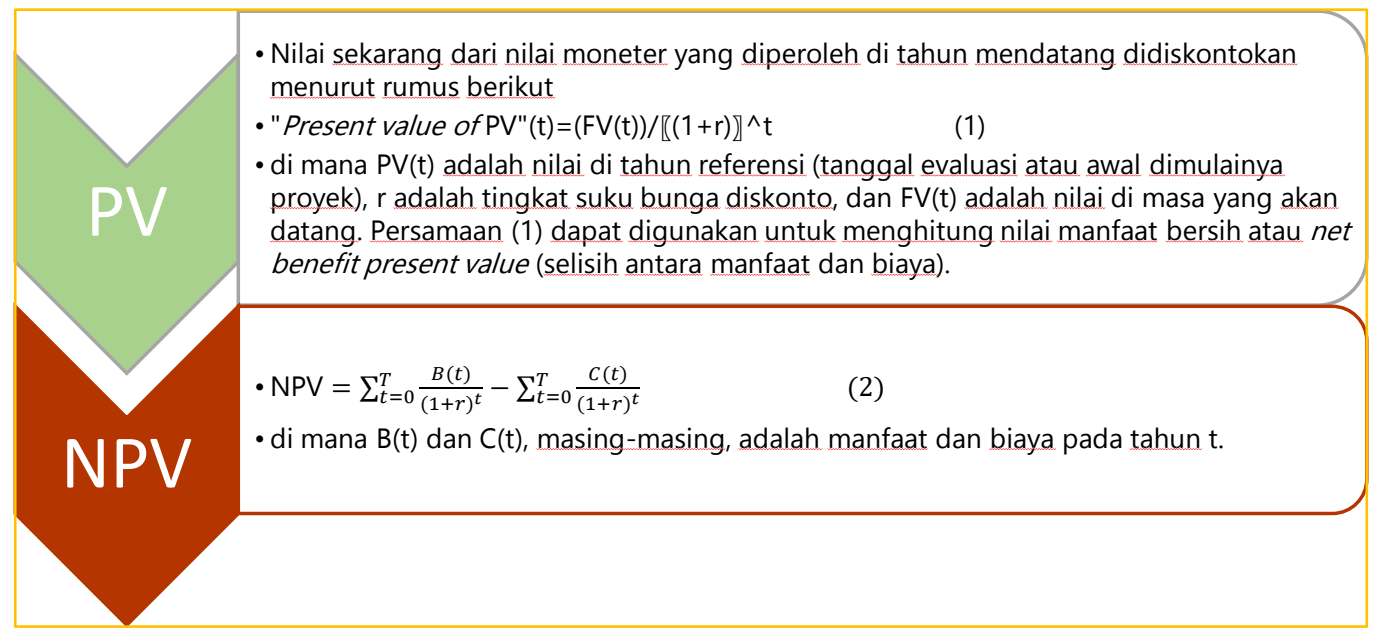

Konsep nilai dari perspektif ekonomi terbagi menjadi nilai guna (use value) dan non-guna (non-use value) yang dipilah menjadi biaya dan manfaat. Dalam CBA ideal, kedua nilai ini diperhatikan, namun karena keterbatasan data laporan kinerja dan keuangan lembaga di daerah, analisis sementara ini terfokus pada nilai guna dan hanya menghitung manfaat publik (dirasakan masyarakat luas), belum manfaat privat (pengalihan biaya BIG ke daerah).

\section{Tinjauan Literatur dan Metode Penelitian}

Metode yang digunakan adalah penelitian kualitatif melalui analisa terhadap data primer berupa angket operasionalisasi simpul jaringan di 34 provinsi yang disebarkan oleh BIG saat penyelenggaraan Rapat Operasionalisasi Simpul JIGN Tingkat Provinsi di 5 region, pada Februari - Mei 2018. Data primer juga diperoleh dari diskusi dengan Kepala UPTD Pemetaan di Kalimantan Timur 
terkait peran kelembagaan simpul jaringan dalam pembangunan melalui penguatan IDSN. ${ }^{7}$ Data sekunder berasal dari berbagai peraturan perundangundangan yang berlaku, khususnya peraturan gubernur terkait pembentukan simpul jaringan dan berbagai literatur terkait.

Selanjutnya hasil penelitian kualitatif diperkuat dengan penelitian kuantitatif dengan cara menilai serta membandingkan dampak dari keempat bentuk kelembagaan informasi geospasial ketika manfaat dan biaya dari kelembagaan tersebut terjadi untuk jangka waktu yang lama. Analisa dilakukan terhadap data sekunder, berupa: a) empat laporan keuangan simpul jaringan daerah yang berasal dari keempat opsi kelembagaan berbeda, b) Laporan Akuntabilitas Kinerja Instansi Pemerintah (LAKIP) BIG tahun 2014 - 2017, serta c) laporan operasionalisasi simpul jaringan oleh BIG di 5 regional.

Keterbatasan data daerah yang terpublikasi formal serta variasi pencatatan keuangan tiap lembaga daerah, membuat peneliti menggunakan dua grup data biaya per opsinya, yakni: 1) angka asumsi proporsi terhadap biaya penyelenggaraan informasi geospasial di BIG (data formal namun asumtif); dan 2) angka yang diperoleh peneliti dari pemangku kepentingan di setiap opsi lembaga melalui komunikasi tanpa dokumentasi resmi (data informal namun real). Hipotesanya adalah kedua angka ini memiliki urutan skala nilai yang selaras. Sedangkan elemen manfaat tiap opsinya didasari peningkatan jumlah akses dan variasi IGT yang dapat dibagi pakaikan untuk penelitian, berupa data wajib maupun tambahan, demi mendukung pencapaian RPJMN dan KSP. Terdapat total 9 komponen biaya dan 5 komponen manfaat yang dievaluasi, mengacu pada LAKIP BIG. Peneliti menggunakan asumsi bahwa tiap provinsi memiliki kualitas informasi geospasial yang sama. Diasumsikan pula, manfaat dapat dihitung ketika persiapan kelembagaan tersebut selesai, yakni pada tahun 2022.

Data biaya dan manfaat, yang berlaku umum untuk seluruh opsi maupun yang berlaku spesifik pada tiap opsi, diinput ke dalam MS Excel sebagai sumber informasi perhitungan CBA. Untuk menghitung NPV seluruh periode perhitungan, present value per tahun pada tiap opsi lembaga sejak 2018 hingga 15 tahun ke depan, dihitung terlebih dahulu. NPV positif berarti manfaat melebihi biayanya, begitu pula sebaliknya bila negatif. Kemudian, rasio manfaat/biaya dihitung, dimana nilai $>1$ berarti seberapa besar pengalian biaya mengungkit realisasi dari manfaat. Tahap akhir yakni membandingkan hasil keempat opsi, untuk mendapatkan kesimpulan bentuk lembaga terbaik.

\section{Hasil Temuan dan Analisis}

Kelembagaan JIGN saat ini baru pada tahap pengembangan, belum dapat sepenuhnya lepas landas untuk mewujudkan keberhasilan Visi Indonesia

${ }^{7}$ FGD Kajian Kelembagaan Informasi Geospasial dengan Kepala UPTD Pemetaan (One Data One Map) di Bappeda Provinsi Kaltim dan perwakilan Direktorat Tata Ruang Bappenas pada 26 April 2018. 
2045 dalam rangka mendukung pemerataan pembangunan. Status kelembagaan informasi geospasial di Indonesia pada tingkat pusat hingga Oktober 2018, baru terdapat 9 dari 19 Kementerian/Lembaga yang simpul jaringannya telah operasional. Sementara di tingkat daerah, baru 20 dari 34 provinsi yang operasional dan penyebarannya belum merata di berbagai regional di Indonesia.

Oleh karena itu, dalam rangka pemenuhan sasaran pemerataan pembangunan sesuai visi 2045, maka arah penataan kelembagaan informasi geospasial yang berkelanjutan adalah kemampuan seluruh provinsi dan kabupaten/kota untuk membentuk simpul jaringan sesuai kemampuannya masing-masing. Fungsi utama simpul jaringan adalah memperkuat IDSN dalam rangka penyediaan basis dan analisis spasial yang akurat dan dapat dibagi pakaikan, sejalan dengan KSP dan KSDI. Ini karena data spasial sebagai output simpul jaringan yang sesuai standar bukanlah lahir dari suatu proses yang instan sehingga menambah tumpang tindih data, melainkan melibatkan 5 pilar IDSN agar penyelenggaraan data menjadi efisien dan efektif. Untuk itu, pelaksanaan tugas dan fungsi simpul jaringan diharapkan bersifat terfokus dan terukur, bukan lagi sekedar ditandem.

Sejalan dengan KSP, maka tujuan dari simpul jaringan adalah layanan ketersediaan basis dan analisis spasial lintas sektor dan lintas wilayah terkait berbagai potensi sumber daya di Indonesia, yang dimanfaatkan dan dibagi pakaikan untuk pemerataan pembangunan secara berkelanjutan. Hasil pemetaan dasar dan tematik digunakan untuk mengatasi ketimpangan pembangunan antara perdesaan dan perkotaan, antara Pulau Jawa dan luar Jawa, antara pusat-pusat pertumbuhan dan kawasan perbatasan, serta antara Kawasan Barat Indonesia dan Kawasan Timur Indonesia.

Lebih jauh, peran strategis simpul jaringan dalam mendukung pemerataan pembangunan pada tahap IV RPJM 2020 - 2024 adalah mewujudkan ketersediaan peta skala besar (1:5.000 - 1:1.000) untuk kebutuhan Rencana Detail Tata Ruang (RDTR), Ini sangat berguna bagi program terkait dengan pengentasan kemiskinan, pemerataan usaha dan pendapatan, serta pembangunan infrastruktur yang terintegrasi.

Sasaran dalam penataan kelembagaan simpul jaringan sesuai Visi Indonesia 2045 adalah terwujudnya pemanfaatan ruang yang harmonis dengan dokumen perencanaan tata ruang, meningkatkan pemerataan pendapatan dan kesejahteraan masyarakat serta mampu mencegah risiko konflik dan kebencanaan. Oleh karena itu, penilaian terhadap keempat opsi simpul jaringan dalam penguatan IDSN meliputi kategori sebagaimana diuraikan dalam Tabel 2 berikut ini. 
Tabel 2. Kategori Simpul Jaringan yang mendukung IDSN

\begin{tabular}{|c|l|l|}
\hline No. & \multicolumn{1}{|c|}{ Pilar IDSN } & \multicolumn{1}{c|}{ Kategori } \\
\hline 1. & $\begin{array}{l}\text { Kebijakan } \\
\text { Kelembagaan }\end{array}$ & $\begin{array}{l}\text { Ketersediaan rencana induk, unit kerja, } \\
\text { berbagi pakai data, level eselonisasi, jalur } \\
\text { birokrasi, wali data, forum data. }\end{array}$ \\
\hline 2. & Data dan Standar & $\begin{array}{l}\text { Ketersediaan 3 data minimal, tambahan data } \\
\text { terbanyak sesuai KUGI v.5, SOP dan } \\
\text { pemutakhiran data, pembagian data terbuka } \\
\text { dan rahasia. }\end{array}$ \\
\hline 3. & Teknologi & $\begin{array}{l}\text { Kelengkapan hardware dan software, serta } \\
\text { pemeliharaan dan perawatan alat. }\end{array}$ \\
\hline 4. & Sumber daya manusia & $\begin{array}{l}\text { Ketersediaan beragam profesi sebagai } \\
\text { pelaksana teknis, kinerja terukur, rotasi atau } \\
\text { mutasi SDM bersifat internal, pembinaan } \\
\text { SDM. }\end{array}$ \\
\hline
\end{tabular}

Analisa kelembagaan dilakukan dengan menilai 3 (tiga) faktor penting dari aspek kelembagaan simpul jaringan yaitu kewenangan koordinasi yang kuat, bobot kerja yang proporsional, dan pembagian anggaran. Hal ini diuraikan dalam Tabel 3 berikut.

Tabel 3. Faktor utama Simpul Jaringan dalam Pengembangan IDSN

\begin{tabular}{|l|l|l|l|}
\hline Opsi & $\begin{array}{l}\text { Kewenangan } \\
\text { koordinasi }\end{array}$ & Bobot kerja & Pembagian anggaran \\
\hline 1. UPT & $\begin{array}{l}\text { Kuat, } \\
\text { dipimpin } \\
\text { kepala UPT } \\
\text { pada level } \\
\text { eselon Illa }\end{array}$ & $\begin{array}{l}\text { Proporsional, } \\
\text { terfokus dan } \\
\text { terukur. }\end{array}$ & Tinggi di level bidang. \\
\hline 2. Bappeda & $\begin{array}{l}\text { Lemah, } \\
\text { dipimpin } \\
\text { kepala sub } \\
\text { bidang level } \\
\text { eselon IV }\end{array}$ & $\begin{array}{l}\text { Berat dan ditandem, } \\
\text { karena fokus banyak } \\
\text { terbagi pada } \\
\text { pencapaian 5 } \\
\text { sasaran prioritas } \\
\text { daerah sesuai } \\
\text { RPJMD \& RKPD }\end{array}$ & $\begin{array}{l}\text { Rendah di level sub } \\
\text { bidang. Program dan } \\
\text { anggaran terbatas. }\end{array}$ \\
\hline $\begin{array}{l}\text { 3. Ad Hoc } \\
\text { Sekda }\end{array}$ & $\begin{array}{l}\text { Sangat kuat, } \\
\text { dipimpin } \\
\text { oleh Sekda di } \\
\text { level eselon } \\
\text { 1b }\end{array}$ & $\begin{array}{l}\text { Tidak ada unit kerja, } \\
\text { hanya unit } \\
\text { fungsional. Peran } \\
\text { hanya sebagai } \\
\text { koordinator. Unit } \\
\text { kerja berada di }\end{array}$ & $\begin{array}{l}\text { Rendah, karena hanya } \\
\text { alokasi untuk } \\
\text { koordinasi. } \\
\text { Pengecualian Ad Hoc } \\
\text { di Sekda bisa memiliki } \\
\text { anggaran yang }\end{array}$ \\
\hline
\end{tabular}




\begin{tabular}{|l|l|l|l|}
\hline & & $\begin{array}{l}\text { Bappeda dan OPD } \\
\text { terkait. }\end{array}$ & $\begin{array}{l}\text { proporsional } \\
\text { berdasarkan SK } \\
\text { Gubernur. }\end{array}$ \\
\hline $\begin{array}{l}\text { 4. Diskom } \\
\text { infotik }\end{array}$ & $\begin{array}{l}\text { Lemah, } \\
\text { dipimpin } \\
\text { kepala sub } \\
\text { bidang level } \\
\text { eselon IV }\end{array}$ & $\begin{array}{l}\text { Tandem di Bidang } \\
\text { Statistik, fokus kerja } \\
\text { terbagi dan sangat } \\
\text { minim SDM }\end{array}$ & $\begin{array}{l}\text { Rendah di level sub } \\
\text { bidang. } \\
\text { Program dan } \\
\text { anggaran terbatas. }\end{array}$ \\
\hline
\end{tabular}

Hasil analisa kapabilitas simpul jaringan terhadap ketiga faktor dalam rangka memperkuat IDSN digambarkan dalam bentuk rating bintang, sebagaimana termuat di dalam Tabel 4, Tabel 5, Tabel 6 dan Tabel 7 untuk tiap pilar berikut.

Tabel 4. Penilaian Pilar Kebijakan dan Pilar Kelembagaan

\begin{tabular}{|c|c|c|c|c|c|}
\hline N0 & KRITERIA & OPSI 1: UPTB & OPSI 2: BAPPEDA & OPSI 3: SEKDA & OPSI 4: KOMINFOTIK \\
\hline 1. & Rencana induk & s Jabar, Kaltim & & 令 Kalsel & \\
\hline 2. & $\begin{array}{l}\text { Unit kerja: Produksi, } \\
\text { pengelolaan \& } \\
\text { penyebarluasan }\end{array}$ & S & 象 & Unit fungsional & 落 \\
\hline 3. & Berbagi pakai data & $\begin{array}{c}\text { Lampung, Jabar, } \\
\text { DIY, Kaltim }\end{array}$ & $\begin{array}{c}\text { Sumsel, Kalbar, } \\
\text { Maluku, Malut }\end{array}$ & & is Draft Riau \\
\hline 4. & $\begin{array}{l}\text { Jalur eselonisasi } \\
\text { cukup tinggi }\end{array}$ & s Es. III & Es.IV & 苟 Es.I & $E S_{\text {I IV }}$ \\
\hline 5. & $\begin{array}{l}\text { Jalur birokrasi } \\
\text { pengambilan } \\
\text { keputusan yang } \\
\text { lebih pendek }\end{array}$ & is Efektif & Tidak efektif & Sangat efektif & Tidak efektif \\
\hline 6. & Wali data & $\begin{array}{c}\text { Lampung, } \\
\text { s Jabar, Kaltim, } \\
\text { DIY, Papua }\end{array}$ & s Babel, Sumsel & s Kalsel & s Draft Riau \\
\hline 7. & Forum data & $\begin{array}{l}\text { Lampung, } \\
\text { Jabar, DIY, Kaltim }\end{array}$ & $\begin{array}{c}\text { Sumsel, Kalbar, } \\
\text { Sulsel }\end{array}$ & s Kalsel & \& Draft Riau \\
\hline & Total: & & 4 & 5 & 4 \\
\hline
\end{tabular}


Tabel 5. Penilaian Pilar Data dan Standar

\begin{tabular}{|c|c|c|c|c|c|}
\hline N0 & KRITERIA & OPSI 1: UPTB & OPSI 2: BAPPEDA & OPSI 3: SEKDA & $\begin{array}{c}\text { OPSI 4: } \\
\text { KOMINFOTIK }\end{array}$ \\
\hline 1. & $\begin{array}{l}3 \text { Data minimal } \\
\text { Peta RTRW, Batas } \\
\text { wilayah, MHA }\end{array}$ & $\begin{array}{c}\text { Aceh, DIY, Jatim, } \\
\text { Kaltim }\end{array}$ & $\begin{array}{c}\text { Sumsel, Babel, } \\
\text { Sulteng }\end{array}$ & \&s Sumut, Kalsel & \\
\hline 2. & $\begin{array}{l}\text { Data Tambahan } \\
\text { Terbanyak sesuai } \\
\text { KUGI }(v .5)\end{array}$ & s $\begin{array}{l}\text { Aceh, DIY, Jatim, } \\
\text { Kaltim, Papua }\end{array}$ & $\begin{array}{c}\text { Sumsel, Babel, } \\
\text { ¿s Sulteng, Kalbar, } \\
\text { Sulsel, Malut, Maluku }\end{array}$ & 今 Sumut, Kalsel & Riau \\
\hline 3. & $\begin{array}{l}\text { SOP dan } \\
\text { pemutakhiran data }\end{array}$ & s Jabar, Kaltim, & & & \\
\hline 4. & $\begin{array}{l}\text { Pembagian data } \\
\text { terbuka \& rahasia }\end{array}$ & s Jabar, DIY, Kaltim & 的 Sumsel, Babel & & \& Draft Riau \\
\hline & Total: & 4 & 3 & 2 & 2 \\
\hline
\end{tabular}

Tabel 6. Penilaian Pilar Sumber Daya Manusia

\begin{tabular}{|c|c|c|c|c|c|}
\hline NO & KRITERIA & OPSI 1: UPTB & OPSI 2: BAPPEDA & 0PSI 3: SEKDA & $\begin{array}{c}\text { OPSI 4: } \\
\text { KOMINFOTIK }\end{array}$ \\
\hline 1. & $\begin{array}{l}\text { Beragam profesi } \\
\text { pelaksana teknis: } \\
\text { PNS atau ASN } \\
\text { terakomodasi }\end{array}$ & $\begin{array}{l}\text { Aceh, } \\
\text { \& Jabar, } \\
\text { Kaltim }\end{array}$ & $\begin{array}{r}\text { Sumsel, } \\
\text { Babel, } \\
\text { Sulsel }\end{array}$ & $\begin{array}{ll} & \text { Tersebar } \\
\text { diOPD } \\
\text { terkait }\end{array}$ & $\begin{array}{ll} & \text { Tersebar } \\
\text { s } & \text { diOPD } \\
\text { terkait }\end{array}$ \\
\hline 2. & $\begin{array}{l}\text { Kinerja SDM } \\
\text { terukur }\end{array}$ & 令 $\operatorname{diRKPD}$ & 出 diRKPD & & \\
\hline 3. & $\begin{array}{l}\text { Rotasi dan mutasi } \\
\text { SDM bersifat } \\
\text { internal }\end{array}$ & s & s & & \\
\hline 4. & $\begin{array}{l}\text { Pembinaan SDM } \\
\text { pelaksana IG } \\
\text { dianggarkan di } \\
\text { unit kerja }\end{array}$ & 岛 & & & \\
\hline & Total: & 4 & 3 & 1 & 1 \\
\hline
\end{tabular}

Tabel 7. Penilaian Pilar Teknologi

\begin{tabular}{|c|c|c|c|c|c|c|}
\hline N0 & KRITERIA & & OPSI 1: UPTB & OPSI 2: BAPPEDA & OPSI 3: SEKDA & OPSI 4: KOMINFOTIK \\
\hline 1. & $\begin{array}{l}\text { Kelengkapan } \\
\text { Hardware \& } \\
\text { Software } \\
\text { (Komputer, } \\
\text { internet, jaringan, } \\
\text { server, LAN, SIG) }\end{array}$ & & $\begin{array}{l}\text { Aceh, Jabar, } \\
\text { Jatim, Kaltim }\end{array}$ & s Babel & 年 Kalsel & Riau \\
\hline 2. & $\begin{array}{l}\text { Pemeliharaan \& } \\
\text { perawatan alat }\end{array}$ & 且 & & & & \\
\hline & Total: & & 2 & 1 & 1 & 1 \\
\hline
\end{tabular}


Terlihat dari keempat opsi kelembagaan simpul jaringan di daerah, bahwa opsi 1 UPTB menunjukkan keunggulan tertinggi dengan meraih 17 bintang, disusul oleh opsi 2 Bappeda meraih 11 bintang. Kemudian opsi 3 Ad Hoc di Sekda meraih 9 bintang dan terakhir opsi 4 Diskominfotik dengan 8 bintang. Namun Ad Hoc di Sekda berpotensi besar menjadi simpul jaringan terbaik yang mengungguli Bappeda, karena kepemimpinan eselon 1 menunjang fungsi koordinasi dan sinkronisasi. Oleh karena itu, analisa terhadap simpul jaringan diperkuat dengan penilaian terhadap tantangan regulasi, berikut rekomendasinya sebagaimana diuraikan di dalam Tabel 8 berikut ini.

Tabel 8. Tantangan Regulasi dan Rekomendasi

\begin{tabular}{|c|c|c|c|}
\hline Opsi & Regulasi & Tantangan & Rekomendasi \\
\hline \multirow[t]{2}{*}{ 1.UPT } & \multirow[t]{2}{*}{$\begin{array}{l}\text { Ps. } 17 \text { ayat } \\
\text { (1) } \\
\text { Permendagri } \\
\text { No. 12/2017: } \\
\text { Pedoman } \\
\text { dan } \\
\text { Klasifikasi } \\
\text { Cabang } \\
\text { Dinas \& } \\
\text { UPTD }\end{array}$} & $\begin{array}{l}\text { Pengelolaan data } \\
\text { ditafsirkan } \\
\text { Kemdagri hanya } \\
\text { kewenangan } \\
\text { PPID, sedangkan } \\
\text { UPTB tidak } \\
\text { berwenang. } \\
\text { Akibatnya } 3 \\
\text { UPTD } \\
\text { dibubarkan. }\end{array}$ & $\begin{array}{l}\text { Persamaan persepsi bahwa } \\
\text { UPTB berwenang } \\
\text { mengelola data } \\
\text { berdasarkan Ps. } 274 \text { UU } \\
\text { No. 23/2014: Pemerintahan } \\
\text { Daerah jo. Ps.32 UU No. } \\
\text { 25/2004: Sistem } \\
\text { Perencanaan } \\
\text { Pembangunan Nasional. }\end{array}$ \\
\hline & & $\begin{array}{l}\text { UPT tidak boleh } \\
\text { melakukan } \\
\text { kegiatan } \\
\text { koordinasi, } \\
\text { sinkronisasi dan } \\
\text { terkait langsung } \\
\text { dengan } \\
\text { pengambilan } \\
\text { keputusan. }\end{array}$ & $\begin{array}{l}\text { Revisi pasal ini. Tujuannya } \\
\text { UPT perlu berkoordinasi } \\
\text { teknis dan melakukan } \\
\text { sinkronisasi. Hasilnya } \\
\text { berupa rekomendasi } \\
\text { kebijakan, dan } \\
\text { pengambilan keputusan } \\
\text { tetap berada di tangan } \\
\text { kepala Bappeda. }\end{array}$ \\
\hline 2.Bappeda & $\begin{array}{l}\text { Ps. } 67 \text { PP } \\
\text { No. 18/2016: } \\
\text { Perangkat } \\
\text { Daerah }\end{array}$ & $\begin{array}{l}\text { Badan Provinsi } \\
\text { Tipe A paling } \\
\text { banyak memiliki } 4 \\
\text { bidang. }\end{array}$ & $\begin{array}{l}\text { Bobot kerja pada } 4 \text { bidang } \\
\text { di Bappeda sudah sangat } \\
\text { berat dalam mengawal } 5 \\
\text { prioritas nasional, } 25 \\
\text { program prioritas \& } 102 \\
\text { kegiatan prioritas. Perlu } \\
\text { mencari alternatif } \\
\text { kelembagaan lain. Apabila } \\
\text { bertahan, maka simpul } \\
\text { jaringan perlu dinaikkan ke }\end{array}$ \\
\hline
\end{tabular}




\begin{tabular}{|c|c|c|c|}
\hline & & & $\begin{array}{l}\text { tingkat Bidang pada level } \\
\text { eselon III. }\end{array}$ \\
\hline $\begin{array}{l}\text { 3.Ad Hoc } \\
\text { di Sekda }\end{array}$ & $\begin{array}{l}\text { Ps. } 5 \text { ayat (2) } \\
\text { Perpres No. } \\
\text { 27/ } 2014: \\
\text { JIGN jo. Ps. } 7 \\
\text { ayat ( } 4 \text { a - } \\
\text { d) PP No. } \\
\text { 18/2016 jo. }\end{array}$ & $\begin{array}{l}\text { Simpul jaringan } \\
\text { wajib berbentuk } \\
\text { unit kerja. Tidak } \\
\text { ada unit kerja di } \\
\text { Sekda, hanya unit } \\
\text { fungsional. Ini } \\
\text { karena tugas } \\
\text { Sekda bukan } \\
\text { pengelolaan data. }\end{array}$ & $\begin{array}{l}\text { Peluang dibuka di Ps. } 7 \\
\text { ayat (4e) PP No. 18/2016: } \\
\text { Sekda dapat menjalankan } \\
\text { fungsi lain yang diberikan } \\
\text { oleh gubernur. Jadi sekda } \\
\text { dapat mengelola data dan } \\
\text { mendapatkan anggaran } \\
\text { berdasarkan SK Gubernur. } \\
\text { Sekda berperan sebagai } \\
\text { Ketua TKPRD menurut } \\
\text { Permendagri No. 116/2017: } \\
\text { Koordinasi Penataan } \\
\text { Ruang Daerah. Jadi } \\
\text { tupoksinya sangat erat } \\
\text { dengan kerja simpul } \\
\text { jaringan. }\end{array}$ \\
\hline $\begin{array}{l}\text { 4.Diskom } \\
\text { infotik }\end{array}$ & $\begin{array}{l}\text { Ps. } 62 \text { PP } \\
\text { No. 18/2016: } \\
\text { Perangkat } \\
\text { Daerah }\end{array}$ & $\begin{array}{l}\text { Dinas Provinsi } \\
\text { Tipe A paling } \\
\text { banyak memiliki } 4 \\
\text { bidang. Namun } \\
\text { spasial ditandem } \\
\text { di sub bidang } \\
\text { Statistik di } \\
\text { Diskominfotik. } \\
\text { Program, } \\
\text { anggaran dan } \\
\text { SDM terbatas. }\end{array}$ & $\begin{array}{l}\text { Simpul jaringan perlu } \\
\text { dinaikkan ke tingkat } \\
\text { Bidang pada level eselon } \\
\text { III. Tujuannya agar } \\
\text { memiliki program, } \\
\text { anggaran dan SDM yang } \\
\text { proporsional. }\end{array}$ \\
\hline
\end{tabular}

Hasil analisa kelembagaan ini kemudian diperkokoh dengan analisa biaya - manfaat. Komponen biaya dan manfaat yang teridentifikasi lebih fokus pada perhitungan manfaat publik yaitu yang dirasakan oleh masyarakat luas, sebagaimana diuraikan di dalam Tabel 9 berikut ini, diikuti Tabel 10 berisi daftar pertimbangan dan asumsi yang diambil dalam perhitungan. 
Tabel 9. Komponen Biaya \& Manfaat dari Simpul Jaringan

\begin{tabular}{|c|l|l|}
\hline No. & \multicolumn{1}{|c|}{ Biaya } & \multicolumn{1}{|c|}{ Manfaat } \\
\hline 1 & Investasi barang modal & $\begin{array}{l}\text { Penambahan jumlah penelitian } \\
\text { (asumsi terjadi di tahun ke-5 \& } \\
10)\end{array}$ \\
\hline 3 & Biaya operasional per tahun & Pencapaian RPJMD \\
\hline 4 & Biaya pemeliharaan per tahun & Kebijakan publik \\
\hline 5 & $\begin{array}{l}\text { Biaya pembangunan jaringan } \\
\text { per tahun }\end{array}$ & Mengurangi jumlah konflik tenurial \\
\hline 6 & Biaya pemetaan & \\
\hline 7 & $\begin{array}{l}\text { Biaya penelitian dan promosi } \\
\text { kerjasama }\end{array}$ & $\begin{array}{l}\text { Biaya standarisasi dan } \\
\text { kelembagaan informasi } \\
\text { geospasial }\end{array}$ \\
\hline 9 & $\begin{array}{l}\text { Biaya pengelolaan dan } \\
\text { diseminasi informasi geospasial }\end{array}$ \\
\hline
\end{tabular}

Tabel 10. Pertimbangan \& Asumsi Perhitungan Biaya-Manfaat

\begin{tabular}{|c|l|l|}
\hline No. & \multicolumn{1}{|c|}{ Biaya } & \multicolumn{1}{|c|}{ Manfaat } \\
\hline 1 & $\begin{array}{l}\text { Variasi pencatatan keuangan lembaga membuat data biaya per } \\
\text { opsi berbeda-beda }\end{array}$ & Tiap provinsi memiliki kualitas IG sama \\
\hline 2 & $\begin{array}{l}\text { Tiap lembaga menggunakan 2 alternatif perhitungan: asumsi } \\
\text { proporsi biaya penyelenggaraan IG di BIG \& data biaya real yang } \\
\text { diperoleh dari informal channel ke stakeholder daerah }\end{array}$ & $\begin{array}{l}\text { Manfaat muncul setelah tahap persiapan usai (tahun 2022), } \\
\text { diskonto 5\% per tahun }\end{array}$ \\
\hline 3 & \multicolumn{2}{|c|}{ Periode perhitungan: 15 tahun sejak 2018. } \\
\hline 4 & \multicolumn{2}{|c|}{ Seluruh nilai diubah ke present value yang kemudian dibandingkan, selisihnya menjadi net present value (NPV) } \\
\hline
\end{tabular}

Proses input data dasar maupun per opsi, serta perhitungan biaya manfaatnya, menggunakan MS Excel seperti diilustrasikan pada Gambar 4, Gambar 5 dan Gambar 6 berikut ini. 


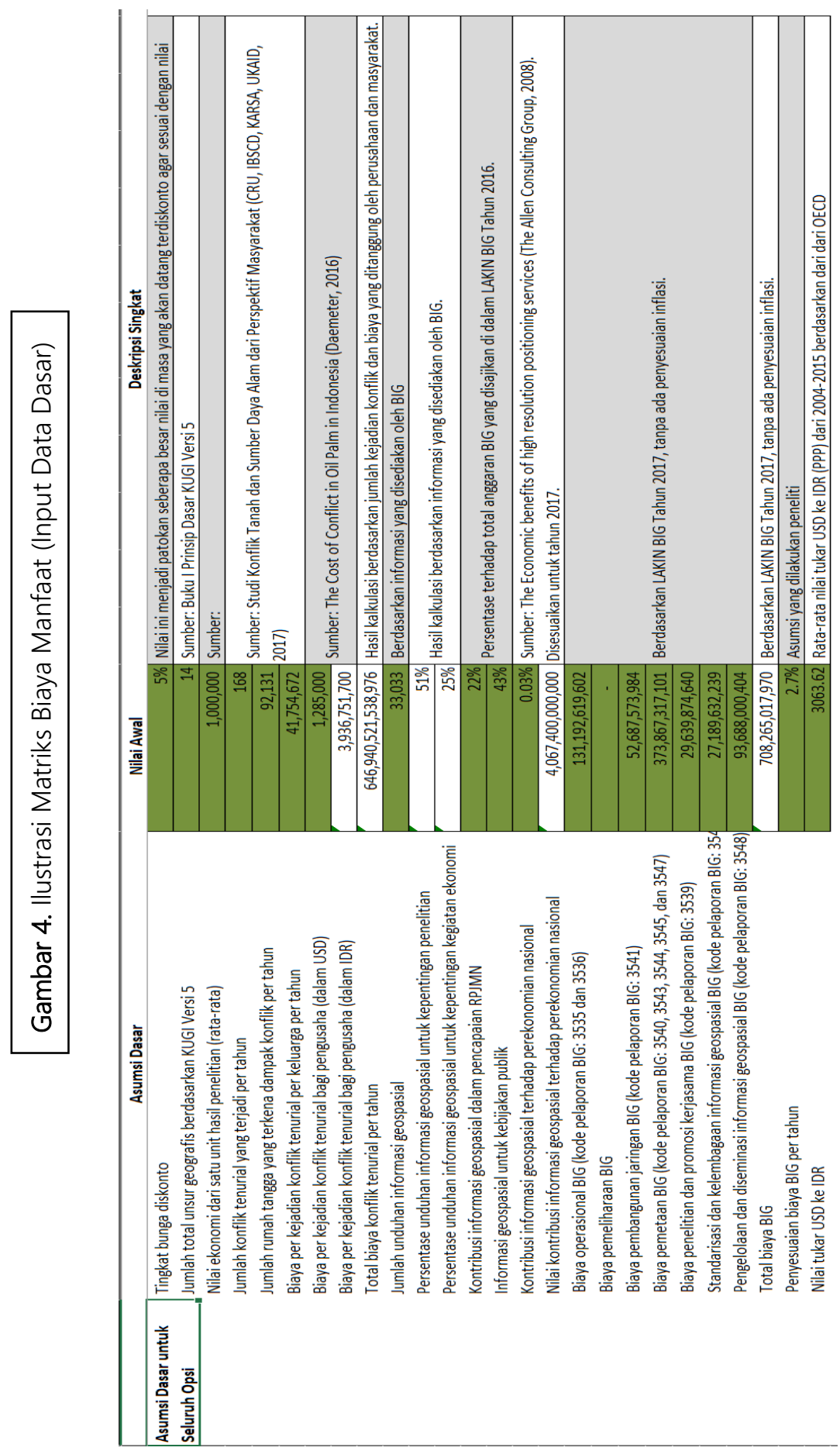




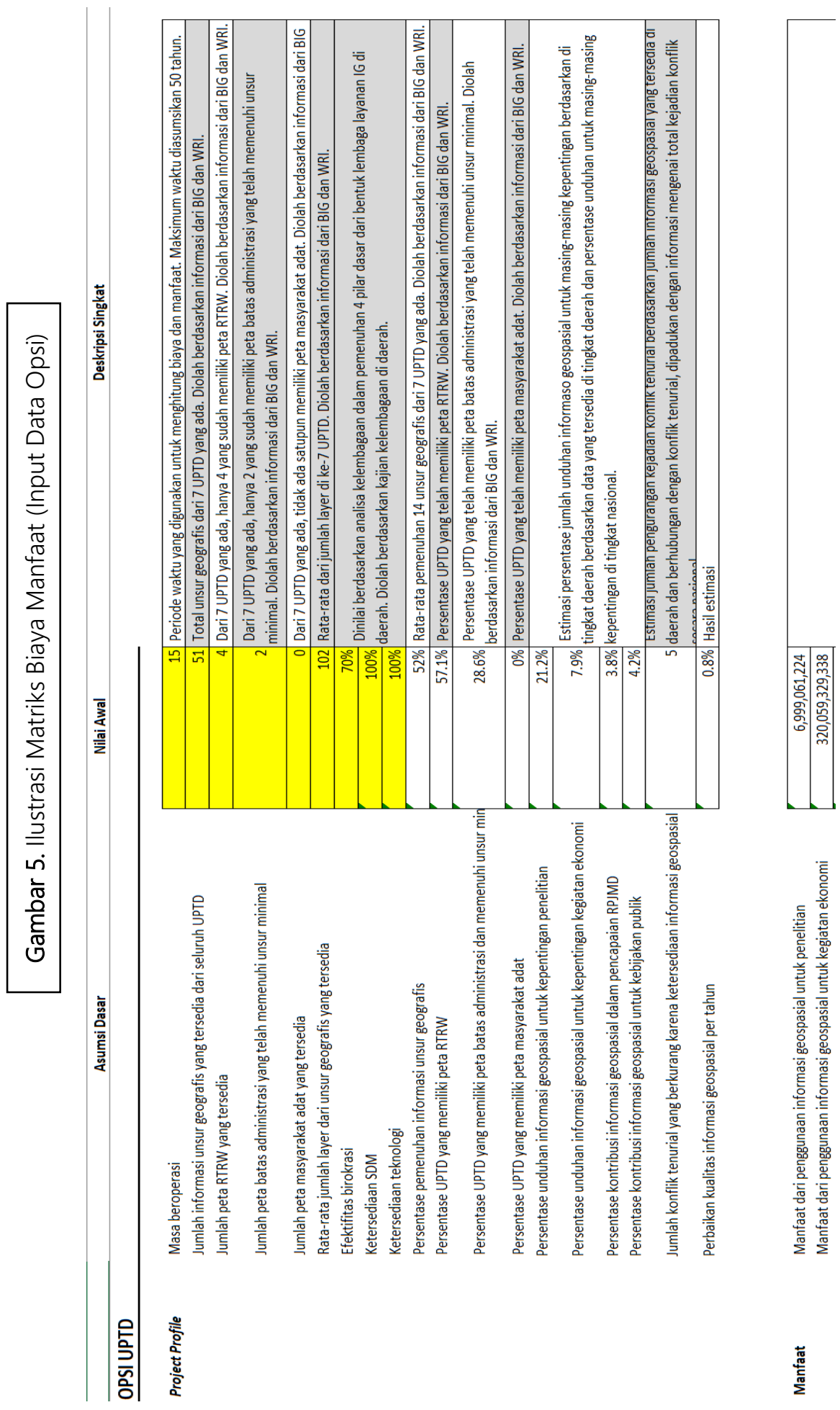




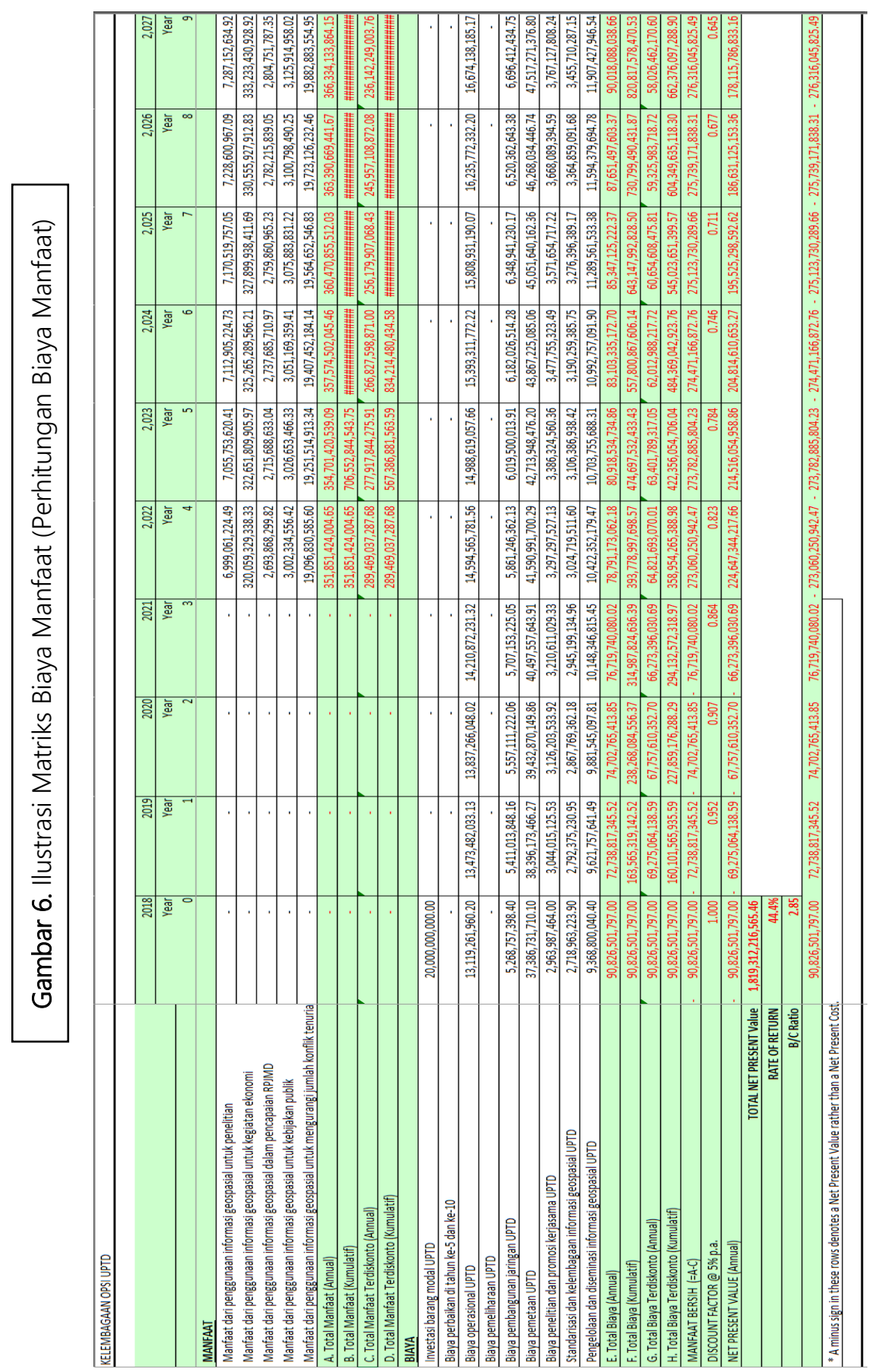


Dari analisa kelembagaan dan biaya-manfaat, maka alternatif kelembagaan yang direkomendasikan dengan nilai terbaik adalah UPTD dan $A d$ Hoc Sekda. Tabel 11 memberi hasilnya berurut dari tertinggi ke terendah:

Tabel 11. Hasil Analisis CBA

\begin{tabular}{|c|c|c|c|c|c|}
\hline \multirow{2}{*}{$\begin{array}{c}\text { P } \\
\text { S } \\
\text { I }\end{array}$} & \multirow{2}{*}{$\begin{array}{c}\text { Bentuk } \\
\text { Lembaga }\end{array}$} & \multicolumn{2}{|c|}{ Data Biaya Formal namun Asumtif } & \multicolumn{2}{c|}{ Data Biaya Informal namun Real } \\
\cline { 3 - 6 } & NPV Kumulatif & Rasio & NPV Kumulatif & Rasio \\
\hline 1 & UPTD & IDR 1,8 Triliun & 2.85 & IDR 2,7 Triliun & 73.9 \\
\hline 2 & Bappeda & - IDR 2 Juta & 0.99 & IDR 431 Miliar & 38.9 \\
\hline 3 & Ad Hoc Sekda & IDR 1,1 Triliun & 2.15 & IDR 2,1 Triliun & 193.7 \\
\hline 4 & Dinas Kominfo & - IDR 937 Miliar & 0.03 & IDR 16 Miliar & 2.7 \\
\hline
\end{tabular}

Grafik perbandingan perhitungan biaya-manfaat tahunan simpul jaringan antara opsi dan dua grup biaya data di atas, dijabarkan dalam Gambar 7 dan Gambar 8 berikut ini.

Gambar 7. Perbandingan Lembaga Simpul Jaringan (data biaya formal namun asumtif)

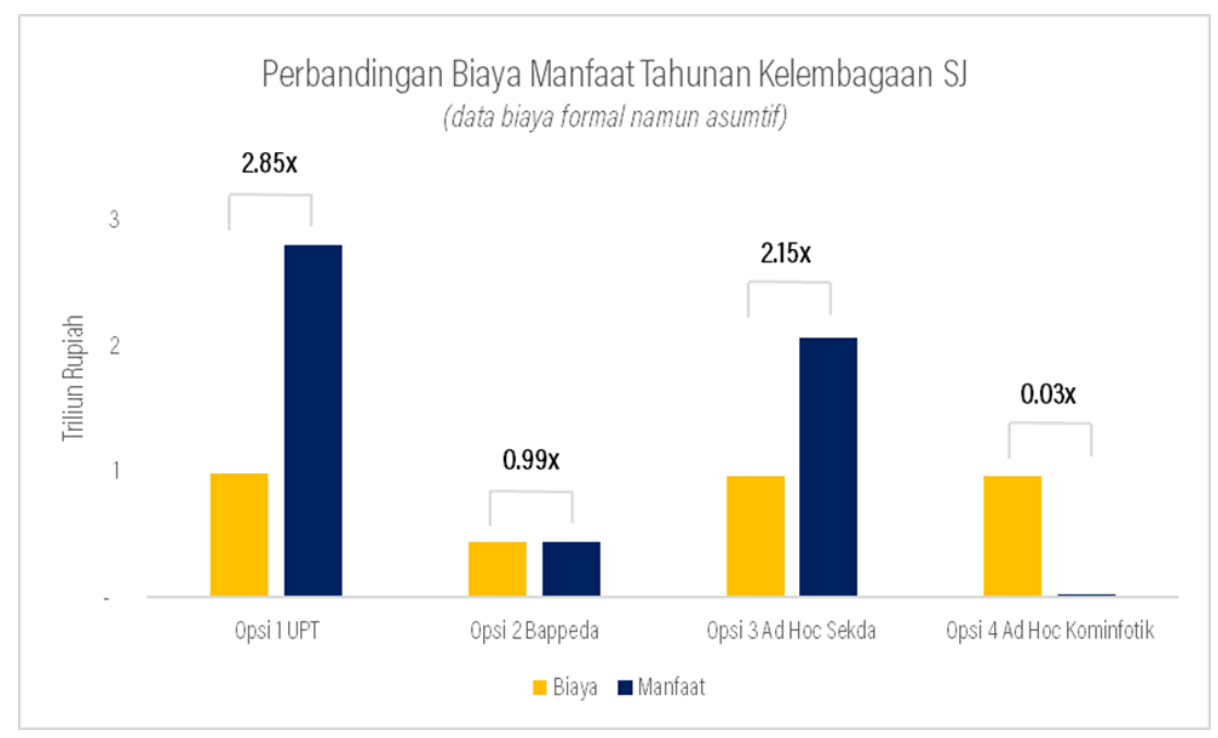


Gambar 8. Perbandingan Lembaga Simpul Jaringan (data biaya informal namun real)

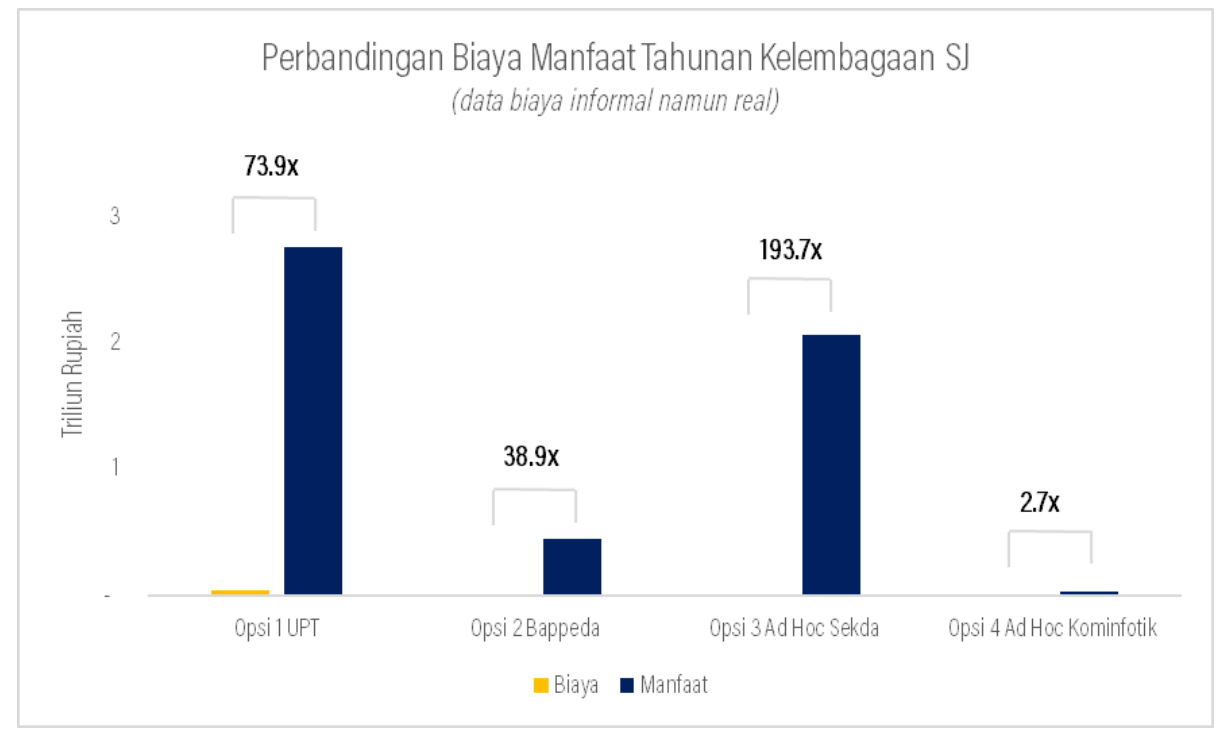

Dari kedua alternatif tertinggi yaitu UPTD dan Ad Hoc di Sekda, pemerintah dapat merumuskan strategi dan tahapan yang jelas dalam mencapai reformasi penataan kelembagaan, sebagai berikut:

1. Tahap Pembangunan Simpul Jaringan (2020 - 2024)

- Penguatan kelembagaan simpul jaringan melalui dukungan Menteri Dalam Negeri dalam bentuk harmonisasi kebijakan organisasi perangkat daerah, terutama bagi UPTD. Pilihan tetap terbuka bagi pemerintah daerah, dengan memperhatikan kesiapan anggaran dan IDSN.

- Penguatan kelembagaan simpul jaringan di tingkat pusat dan daerah melalui dukungan Menteri PPN/Bappenas, yakni penguatan IDSN oleh JIGN agar diintegrasikan pada Prioritas Nasional "Pengurangan Kesenjangan antar Wilayah" pada RKP 2019 dan RPJMN Tahap IV 20202024, agar memiliki jaminan anggaran \& Indeks Kinerja Utama (IKU) terukur, berkelanjutan, dan dapat diturunkan ke dalam RPJMD \& RKPD.

2. Tahap Penguatan Simpul Jaringan (2024 - 2025)

- Penyusunan Grand Design KSP oleh BIG yang terintegrasi dengan Rencana Aksi Satu Data Indonesia.

Grand Design ini memuat peran strategis JIGN dalam menyelenggarakan basis dan analisis spasial terkait pemerataan pembangunan. Salah satu prioritas program simpul jaringan adalah mewujudkan ketersediaan peta-peta tematik skala besar (1:5.000 1:1.000) untuk kebutuhan RDTR, yang berguna bagi program terkait 
pengentasan kemiskinan, pemerataan usaha dan pendapatan, serta pembangunan infrastruktur yang terintegrasi.

- Kerjasama dengan Pusat Pengembangan Infrastruktur Data Spasial (PPIDS) dan mitra pembangunan dalam pembinaan simpul jaringan.

BIG bekerjasama dengan para pemangku kepentingan untuk turut membantu simpul jaringan yang menghadapi kesulitan dalam penyediaan data spasial, teknologi dan pengembangan kapasitas sumberdaya manusia.

Hasil perhitungan ekonomi dan analisis Lembaga ini menjadi masukan dalam menindaklanjuti Bhumandala Award yang didasari oleh basis pengetahuan mengenai Geospatial Readiness Index seperti pada Gambar 9 berikut. Kesiapan daerah tidak hanya dalam kelembagaan menjadi perhatian utama di tahun 2019 dan ke depannya.

Gambar 9. Geospatial Readiness Index, Indonesia (2018)

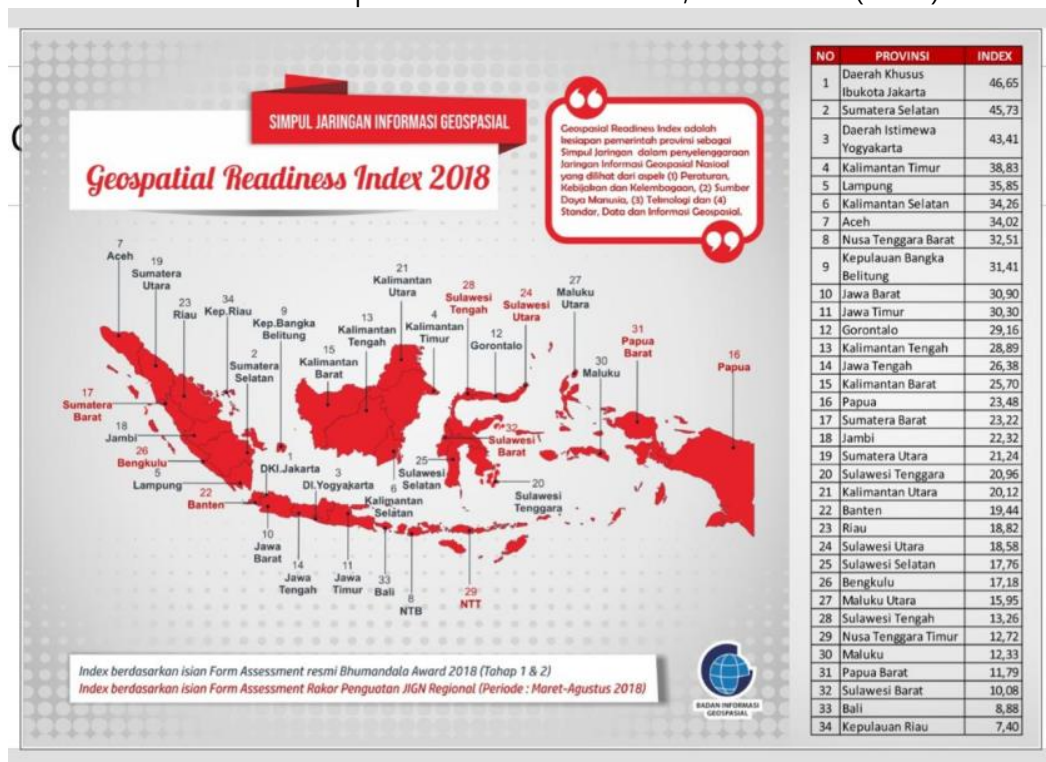

IV. Kesimpulan dan Rekomendasi

5.1. Kesimpulan

- Simpul JIGN ada pada tahap pengembangan, belum dapat lepas landas untuk mendukung pemerataan pembangunan sesuai Visi Indonesia 2045. Oleh karena itu, komitmen dan dukungan pemerintah dalam penataan kelembagaan sangat penting, karena kelembagaan JIGN sebagai penyedia basis dan analisis spasial untuk pemerataan pembangunan wilayah terintegrasi dengan kelembagaan KSP dan KSDI.

- Analisis kelembagaan kualitatif dan biaya-manfaat kuantitatif merekomendasikan 2 alternatif lembaga informasi geospasial dengan nilai terbaik: Opsi 1 UPTB (/dea/jangka panjang) serta Opsi 3 Ad Hoc di Sekda 
(Quick Win jangka menengah). Pilihan dan keputusan tetap terbuka bagi pemerintah daerah, dengan memperhatikan kesiapan anggaran dan IDSN.

5.2. Saran

a. Penguatan IDSN oleh JIGN diharapkan dapat diintegrasikan pada Prioritas Nasional "Pengurangan Kesenjangan antar Wilayah" pada RKP 2019 dan RPJMN tahap IV 2020-2024, agar memiliki jaminan anggaran \& IKU yang terukur, berkelanjutan serta dapat diturunkan ke dalam RPJMD \& RKPD.

b. Peran strategis simpul jaringan sesuai Visi Indonesia 2045 adalah mewujudkan ketersediaan basis dan analisis spasial lintas sektor lintas wilayah untuk pemerataan pembangunan. Salah satu prioritas program bagi JIGN dalam mendukung pemerataan pembangunan adalah mewujudkan ketersediaan peta dasar dan peta tematik skala besar (1:5.000 - 1:1.000) untuk kebutuhan RDTR, yang berguna untuk program terkait pengentasan kemiskinan, pemerataan usaha dan pendapatan, serta pembangunan infrastruktur yang terintegrasi.

Dari analisa di atas, maka penanganan isu kelembagaan lebih urgent dibandingkan dengan process business dalam pengeloaan data. Hal tersebut dikarenakan:

a. Kelembagaan merupakan pintu utama penanggung jawab dalam pelaksanaan tugas simpul jaringan, yakni dalam produksi, pengelolaan dan penyebarluasan informasi geospasial. Urgensinya sebagai basis dan analisis spasial lintas sektor lintas wilayah bagi kebutuhan penyusunan kebijakan dan pengambilan keputusan di daerah.

b. Process business atau SOP dalam pengelolaan data adalah salah satu bagian dalam pilar kelembagaan Infrastruktur Data Spasial Nasional (IDSN). Kelembagaan yang kokoh tentunya akan jadi daya ungkit bagi pembangunan keempat pilar IDSN lainnya yaitu kebijakan, teknologi, sumberdaya manusia, standar dan data.

Beberapa kesulitan dalam implementasi kebijakan satu data antara lain:

1. Kapabilitas kelembagaan informasi geospasial $(I G)$ yang terintegrasi dengan kelembagaan kebijakan satu data. Status kelembagaan IG yang telah operasional per November 2018, di tingkat pusat, baru ada $8 \mathrm{KL}$, sementara di tingkat daerah provinsi, baru 19 yang operasional.

2. Eksistensi kelembagaan UPTB sebagai simpul jaringan dimana 3 diantaranya telah dibubarkan oleh Kemendagri. Padahal ketiganya berprestasi dan meraih Bhumandala Award sebagai simpul jaringan IG terbaik.

3. Struktur organisasi bagi unit kerja simpul jaringan yang berada di Bappeda dan Diskominfotik ditaruh pada level sub bidang eselon IV, sehingga keterbatasan dalam fungsi koordinasi, program dan anggaran. Oleh karena itu, simpul jaringan perlu ditingkatkan pada level Bidang eselon III. 
4. Minimnya anggaran bagi pengembangan IDSN oleh simpul jaringan. Oleh karena itu, RPJMN dan RPJMD 2019 perlu memuat program terkait pengelolaan IG agar terukur, terarah dan terjamin anggarannya.

Waktu yang diperlukan untuk menyiapkan dan memuat kebijakan satu peta (KSP) adalah bertahap, yaitu:

a. Periode 2016 - 2019, KSP telah dilaksanakan oleh kementerian/lembaga/pemerintah daerah sesuai target di dalam Rencana Aksi Nasional KSP, sebagaimana tertuang di dalam Lampiran Perpres No. 9 Tahun 2016 tentang Percepatan Pelaksanaan KSP. Untuk simpul jaringan tingkat provinsi, kompilasi dan integrasi 3 data minimal pada geoportal telah dilaksanakan yaitu Peta RTRWP, Peta Batas Administrasi Provinsi dan Peta Kawasan Masyarakat Hukum Adat, sesuai Permendagri No. Surat Edaran Menteri Dalam Negeri Nomor: 503/685A/SJ tanggal 2 Februari 2018.

b. Tahap selanjutnya Periode 2020 - 2045 adalah penyediaan peta dasar dan peta tematik baik skala besar dan menengah (1:5.000 - 1:1.000), untuk kebutuhan pemerataan pembangunan sesuai Visi Indonesia 2045. Kebutuhan utama terkait penyusunan RDTR, yang berguna untuk program terkait pengentasan kemiskinan, pemerataan usaha dan pendapatan, serta pembangunan infrastruktur yang terintegrasi.

\section{Daftar Pustaka}

------Laporan Akuntabilitas Kinerja Instansi Pemerintah (LAKIP) Kementerian Agraria dan Tata Ruang (ATR) Tahun 2015.

------Laporan Akuntabilitas Kinerja Instansi Pemerintah (LAKIP) Badan Informasi Geospasial (BIG) Tahun 2014-2017.

------Laporan Kegiatan Pelaksanaan Rapat Koordinasi Operasionalisasi Simpul Jaringan di 5 Region, Badan Informasi Geospasial, Oktober 2018.

Abidin, Hasanuddin Z. "Peranan Informasi Geospasial dalam Percepatan Pembangunan Nasional", Disampaikan di ITB Bandung, 20 Januari 2018.

Brodjonegoro, Bambang. "Mencapai Target SDGs untuk Pembangunan Indonesia Jangka Panjang", Disampaikan di ITB Bandung, 26 Agustus 2017. Lihat juga Draf Visi Indonesia 2045 dan Impian Indonesia 2015 2085 oleh Bappenas.

Price Waterhouse Coopers (PWC), "The World in 2050, Will the Shift of The Global Economic Power Continue?", February 2015.

Pusdatin. "Pembangunan Simpul Jaringan Nasional dalam Implementasi Kebijakan Satu Data Indonesia sebagai Payung Besar Pengelolaan Data Spasial Nasional", Kementerian PPN/Bappenas, Bogor, 2018.

Silalahi, Anita dan Martin Siyaranamual. "Analisa Manfaat Biaya Terhadap Model Kelembagaan Pemerintah Daerah Dalam Rangka Penguatan Simpul Jaringan Informasi Geospasial Nasional", World Resources Institute Indonesia, September 2018. 